\title{
SYSTEMATIC UNEQUAL DISSECTION OF OPPOSING VALLEY SIDES
}

\author{
By Richard S. Liebling and Horst S. Scherp \\ (Department of Geology and Geography, Hunter College, New York, New York 10021, U.S.A.)
}

\begin{abstract}
In the Nahoni Range of the northern Ogilvie Mountains, Yukon Territory, Canada, dissection channels are most markedly developed on valley sides facing the north and north-east. The extent of slope channelling is controlled by intensity of insolation and its influence on persistence of snow and ice. Upon the cooler north- and north-east-facing slopes, snow and ice remain well into midsummer; melt water is released over a long period and its discharge is restricted to narrow rivulets. In contrast, snow and ice on the warmer west- and south-facing slopes melt rapidly during the late spring months. The scree on these valley sides moves down-slope as a more or less uniform mass of water-saturated detritus.
\end{abstract}

RÉsumÉ. Découpage systematiquement inégal des flancs opposés des vallées. Dans la chaîne de Nahoni, au Nord des Monts Ogilvie, dans le territoire du Yukon, au Canada, les ravins entaillant les versants sont beaucoup plus développés sur les flancs de vallée faisant face au Nord et au Nord-Est. Le degré de découpage des pentes est contrôlé par l'intensité de l'insolation et son influence sur la persistance de la neige et de la glace. Sur les pentes plus froides regardant le Nord et le Nord-Est, la neige et la glace subsistent jusqu'au milieu de été; de l'eau de fusion est envoyée pendant longtemps et son débit est réduit à d'étroits ruisseaux. Au contraire, la neige et la glace, sur les pentes plus chaudes face à l'Ouest et au Sud, fondent rapidement pendant les mois de la fin du printemps. Les éboulis de ces versants descendent en masse plus ou moins uniforme de sédiments saturés d'eau.

ZUSAMMENFASSUNG. Systematisch ungleichmässige Zergliederung gegenüberliegender Talflanken. In der Nahoni Range der nördlichen Ogilvie Mountains, Yukon Territory, Kanada, sind die Zergliederungsrinnen sehr ausgeprägt an NO-exponierten Talflanken entwickelt. Das Ausmass der Hangzergliederung hängt von der Intensität der Sonneneinstrahlung und deren Einfluss auf die Dauer der Bedeckung mit Schnee und Eis ab. Auf den kühleren N- und NO-exponierten Hängen bleiben Schnee und Eis leicht bis in den Mittsommer erhalten; Schmelzwasser fliesst über eine lange Periode und sein Abfluss ist auf enge Bachläufe beschränkt. Im Gegensatz dazu schmilzt Schnee und Eis auf den wärmeren W- und S-exponierten Hängen während der späten Frühlingsmonate schnell weg. Das Verwitterungsmaterial auf diesen Talflanken bewegt sich hangabwärts als eine mehr oder weniger gleichförmige, wassergesättigte Geröllschicht.

\section{INTRODUCTION}

Asymmetrical topographic features related to slope aspect are frequently observed in regions having periglacial and glacial climatic regimens. Cirques are often more prevalent on cooler, north- and eastfacing slopes, where firn accumulations are preserved for longer periods during the summer and physical weathering is more intense (Derbyshire and Evans, [ $\left.{ }^{\mathrm{c}} 1976\right]$ ). Valley cross-sectional asymmetry is also commonly encountered, but its relationship to aspect is less uniform. In some regions, valley slopes facing north and east are steeper; in others, the steeper slopes are south- and west-facing (Kennedy, $\left[{ }^{c} 1976\right]$ ). This paper describes another form of asymmetry: the remarkably unequal erosional patterns which have developed on opposing valley sides in parts of the Nahoni Range of the northern Ogilvie Mountains, Yukon Territory, Canada. North- and north-east facing slopes are, as a rule, more intensely dissected than those directed to the south and west; indeed, many of the latter show no dissection at all (Fig. la and b).

\section{OBSERVATIONS AND DISCUSSION}

During late spring and early summer, melt-water discharge rates are observed to vary according to valley side orientation. By late May or early June, all snow has melted on south- and west-facing slopes. During this period, detritus on the slopes is water-saturated. In contrast, even into early July, individual accumulations of snow are still found on north- and north-east facing slopes. The long presence of slowly 


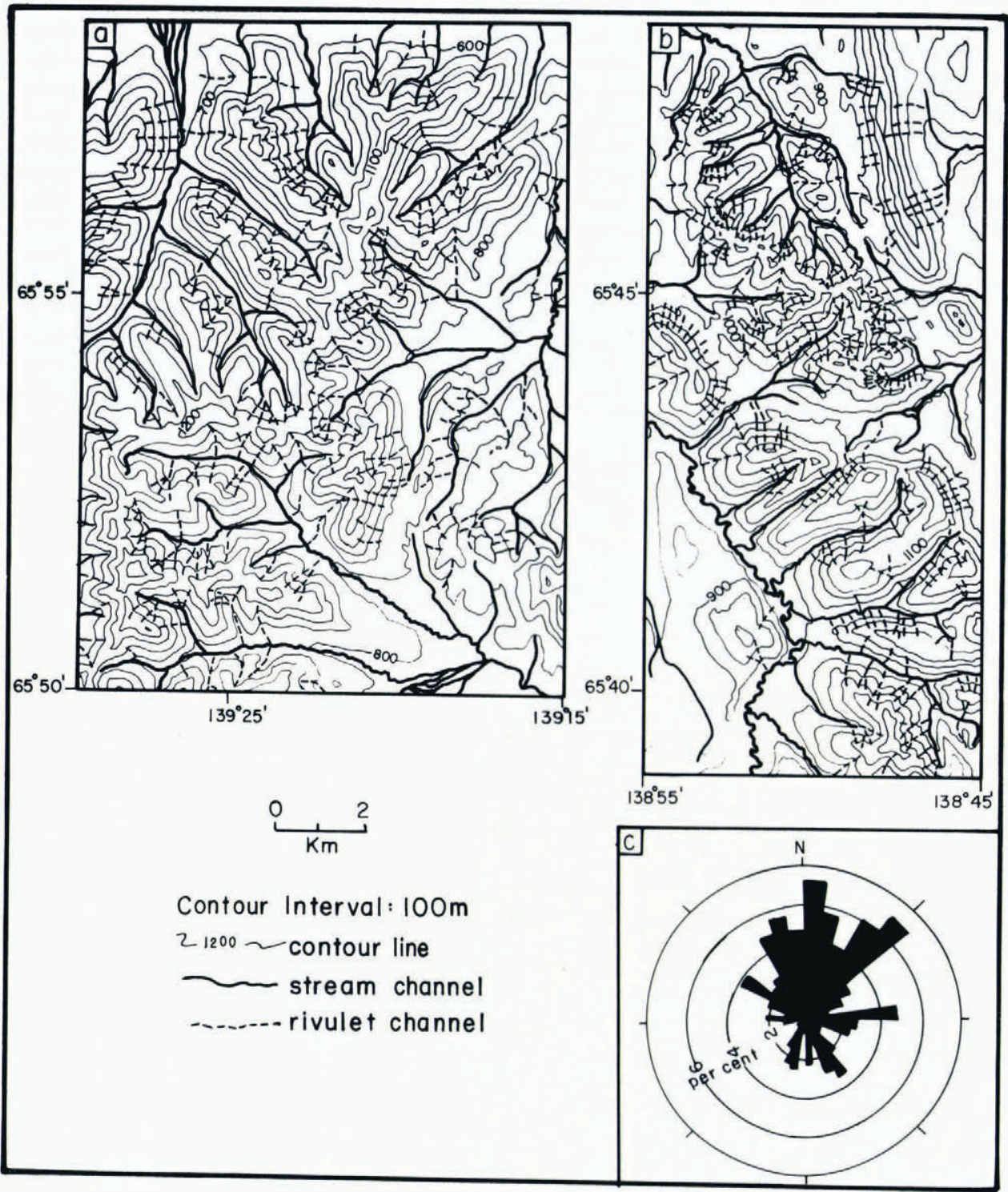

Fig. 1. (a) and (b): Drainage networks within regions studied (1:50000 quadrangles, 116G/14, 116G/10, and $116 G / 15)$. (c): Frequency distribution of rivulet channel orientations.

melting snow on these slopes tends to result in rivulets of water discharging down-slope from each patch and embankment of snow.

To assess the relationship between valley side orientation and the degree of its dissection, a frequency distribution diagram of channel orientations for the valley-side rivulets was constructed (Fig. 1c). It is apparent that channel development is essentially a function of slope bearing and is most marked on those slopes facing the north and north-east.

The extent of slope dissection must therefore, to a great degree, be controlled by intensity of insolation 
and its influence on persistence of snow cover and rate of discharge of melt water provided by snow and ground ice. The lower temperatures experienced by north- and north-east-facing slopes as compared to slopes of southern and western aspect account for the observed longer persistence of snow patches and ground ice on slopes of northerly bearing. As a consequence, marked differences in rate of melt-water discharge and extent to which melt water is concentrated into distinct flow channels exist on slopes of different aspect. Warmer slopes experience rapid melting of snow and ground ice, with consequent saturation of the talus apron occupying the sides of the valley. With underlying bedrock serving as an impermeable sub-surface, detritus is rendered mobile and moves down-slope by gelifluction in a manner sufficiently uniform as to preserve generally smooth contours to the slope. In contrast, the surface cover and bedrock of the cooler slopes, sustaining a slower release of melt water, restricted to rivulets, experience erosion in narrow channels. Once formed, these channels become preferred lines of erosion.

Another factor which may contribute to the asymmetry of dissection is the predominance of carbonate rocks in the region. Melt water on cooler slopes might well contain a greater amount of dissolved $\mathrm{CO}_{2}$, thereby increasing the extent of carbonate solution on slopes of northern and north-eastern aspect.

MS. received 17 March 1982 and in revised form 21 September 1982

\section{REFERENCES}

Derbyshire, E., and Evans, I. S. ['1976.] The climatic factor in cirque variation. (In Derbyshire, E., ed. Geomorphology and climate. New York, John Wiley and Sons, Inc., p. 447-94.)

Kennedy, B. A. ['1976.] Valley-side slopes and climate. (In Derbyshire, E., ed. Geomorphology and climate. New York, John Wiley and Sons, Inc., p. 171-201.) 